\title{
TINDAK TUTUR MENYILAQ PADA MASYARAKAT SASAK DI DESA GERENENG, KECAMATAN SAKRA TIMUR
}

\author{
Mudarman ${ }^{1}$, Muh. Ardian Kurniawan ${ }^{2}$ \\ Universitas Hamzanwadi, Universitas Timor ${ }^{2}$ \\ Posel: mudarman8558@gmail.com¹ ${ }^{1}$ muhardika88@yahoo.co.id ${ }^{2}$
}

\begin{abstract}
This research is a pragmatic study which aims to describe the form and strategy of the speech acts that are dazzling to the Sasak people in Gereneng Village, Sakra Timur District. Data collection uses interview techniques, observation, and is supported by a Test questionnaire Completing the Discourse. Data analysis uses the extralingual equivalent method. The results of the study show that the form of the speech act menyilaq using a one-sentence speech, two-sentence speech, threesentence speech, and speech in more than three sentences. Meanwhile, the strategy of silence is done in the order of the opening greetings $>$ apologies $>$ introducing oneself $>$ introducing the owner of the title $>$ delivering the contents / message $>$ hope $>$ asking permission to leave $>$ thank you $>$ closing greetings. In responding to speech acts, the community manifests them in the form of receptive speech and speech rejecting. In the speech accepting the promising strategy, while in the speech refusing to use the strategy: thank you $>$ apology $>$ argumentation $>$ message.
\end{abstract}

Keywords: speech acts; menyilaq; Sasak language; pragmatics.

\begin{abstract}
Abstrak
Penelitian ini merupakan kajian pragmatik yang bertujuan untuk mendeskripsikan bentuk dan strategi tindak tutur menyilaq pada masyarakat Sasak di Desa Gereneng, Kecamatan Sakra Timur. Pengumpulan data menggunakan teknik wawancara, observasi, dan didukung dengan kuesioner Tes Melengkapi Wacana. Analisis data menggunakan metode padan ekstralingual. Hasil Penelitian menunjukkan bentuk tindak tutur menyilaq dilakukan dengan menggunakan tuturan satu kalimat, tuturan dua kalimat, tuturan tiga kalimat, dan tuturan lebih dari tiga kalimat. Sementara itu, strategi menyilaq dilakukan dengan urutan salam pembuka $>$ permohonan maaf $>$ memperkenalkan diri $>$ memperkenalkan pemilik hajat $>$ menyampaikan isi/pesan $>$ harapan $>$ memohon izin pamit $>$ terima kasih $>$ salam penutup. Dalam merespons tindak tutur, masyarakat mewujudkannya dalam bentuk tuturan menerima dan tuturan menolak. Dalam tuturan menerima digunakan strategi berjanji, sedangkan dalam tuturan menolak menggunakan strategi: terima kasih $>$ permohonan maaf $>$ argumentasi $>$ pesan.
\end{abstract}

Kata Kunci: tindak, tutur; menyilaq; bahasa Sasak; pragmatic.

\section{PENDAHULUAN}

Manusia adalah makhluk sosial yang tidak lepas dari interaksi dengan orang lain. Oleh karena itu, dibutuhkan bahasa sebagai penghubung interaksi itu. Setiap orang berusaha untuk berkomunikasi dengan sempurna dan selengkap mungkin. Setiap orang juga berasumsi bahwa setiap ujaran yang dituturkan dipersepsikan sama dan digunakan merujuk kepada hal yang sama oleh mitra tuturnya. Padahal, dalam aktivitas keseharian masyarakat, ujaran-ujaran yang diucapkannya sering kali juga mengandung makna tindakan tertentu. Komunikasi pun dibangun berdasarkan peringkat dalam pemahaman antarpartisipannya. Suatu pemahaman hanya bisa didapatkan apabila seorang mitra tutur mengetahui maksud dari ujaran penutur dalam satu peristiwa tutur yang diwujudkan dalam kalimat-kalimat. Misalnya, dalam kalimat yang mempunyai tujuan untuk memberitahukan, kalimat yang memerlukan 
jawaban, dan kalimat yang meminta lawan tutur untuk melakukan suatu tindakan atau suatu perbuatan. Austin menyatakan ini sebagai bentuk tindak tutur performatif. Searle memperbarui konsep Austin ini dan mengganti tindakan performatif menjadi tindak tutur ilokusi yang selanjutnya ia nyatakan dalam lima wujud: tindak tutur deklaratif, representatif, komisif, direktif, dan ekspresif (Cutting, 2008: 14-15; Nadar, 2009: 16).

Tindak tutur atau tindak ujaran (speech act) mempunyai kedudukan yang sangat penting dalam pragmatik karena tindak tutur adalah satuan analisisnya. Richards dan Allan (dalam Prayitno, 2011: 41) menyatakan bahwa tuturan memilik dua jenis makna, (a) makna proposisi (proportioal meaning) dan (b) makna ilokusi (illocutionary meaning). Makna proposisi disebut dengan makna lokusi, sebab makna ini merupakan dasar makna literal dari ujaran yang dibawa oleh kata-kata dan struktur tertentu yang dikandung oleh ujaran. Adapun makna ilokusi merupakan efek ujaran (tuturan) pada penutur (Pn) atau (O1) terhadap mitra tutur $(\mathrm{Mt})$ atau $(\mathrm{O} 2)$.

Menurut Searle di dalam bukunya Speech Acts: An Essay in The Philosophy of Language (1969, 23-24) dalam Wijana dan Rohmadi (2009: 20) mengemukakan bahwa secara pragmatis setidak-tidaknya ada tiga jenis tindakkan yang dapat diwujudkan oleh seorang penutur, yakni tindak lokusi (locutionary act) ialah tindak tutur untuk menyatakan sesuatu, tindak ilokusi (Ilocutionary act) cenderung tidak hanya digunakan untuk menginformasikan sesuatu, tetapi juga melakukan sesuatu sejauh situasi tuturannya dipertimbangkan secara seksama, dan tindak perlokusi (perlocutionary act) ialah sebuah tuturan yang diutarakan oleh seseorang yang mempunyai daya pengaruh (perlocutionary force) atau efek yang mendengarkannya.

Selanjutnya, menurut Searle (dalam Rahardi, 2007: 36) menggolongkan "tindak tutur ilokusi itu ke dalam lima macam bentuk tuturan yang masing-masing memiliki fungsi komunikatif. Kelima macam bentuk tuturan ialah; asertif (assertives), direktif (directives), ekspresif (expressives), Komisif (Commissives), dan deklarasi (declarations)."

Menurut Searle (dalam Rahardi, 2010: 36) menyatakan direktif (directives), yakni bentuk tutur yang dimaksudkan penuturnya untuk membuat pengaruh agar si mitra tutur melakukan tindakan. Yule (2006: 93) tindak tutur direktif ialah jenis tindak tutur yang dipakai oleh penutur untuk menyuruh orang lain melakukan sesuatu. Jenis tindak tutur ini menyatakan apa yang menjadi keinginan penutur. Jadi, menurut peneliti tuturan direktif ialah tuturan antara penutur dan mitra tutur dimana mitra tutur agar melakukan atau melaksanakan sesuatu apa yang penutur inginkan.

Menurut Searle (dalam Rahardi, 2010: 36) dan Yule (2006: 93), jenis-jenis tuturan direktif ada lima yaitu; memesan (ordering), memerintah (commanding), memohon (requesting), menasehati (advising), dan memberi saran atau merekomendasi (recomending). " Sementara itu, Nadar (2009: 16) hanya menyebut tiga buah jenis tuturan direktif, yaitu seperti command 'memerintah', request 'meminta', invite 'mengundang."'

Oleh Prayitno (2011: 42), realisasi perwujudan tuturan direktif dikelompokkan menjadi enam tipe atau kategori. Keenam kategori tindak tutur direktif tersebut adalah: (1) tipe Memerintah (to order), meliputi sub-TTD memerintah, menyuruh, menginstruksikan, mengharuskan, memaksa, meminjam, dan menyilakan; (2) tipe meminta (to request), meliputi sub-T'TD meminta, mengharap, memohon, dan menawarkan; (3) tipe mengajak 
(to invite), meliputi sub-TTD mengajak, membujuk, merayu, mendorong, mendukung, mendesak, menuntut, menantang, menagih, menargetkan; (4) tipe memberi nasihat (to advice), meliputi sub-DDT menasihati, menganjurkan, menyarankan, mengarahkan, mengimbau, menyerukan, mengingatkan; (5) tipe mengkritik (to critic), meliputi sub-TTD menegur, menyindir, mengumpat, mengecam, marah; dan (6) tipe melarang (to prohibit), meliputi sub-T'TD melarang, mencegah.

Tindak tutur ilokusi dalam komunikasi pada suatu penelitian penting untuk diperhatikan. Sebab, dalam kajian pragmatik, ilokusi membahas sikap dan ekspresi tindakan seseorang dalam komunikasi, dengan kajian tertuju pada penutur dan lawan tutur. Ilokusi sebagai daya yang ditimbulkan oleh pemakainya dapat memengaruhi partisipasi seseorang untuk melakukan tindakan positif atau negatif.

Dalam penelitian ini, peneliti memfokuskan pada bentuk tindak tutur menyilaq pada masyarakat Sasak di Desa Gereneng Kecamatan Sakra Timur. Menyilaq merupakan bagian dari kegiatan dalam proses mengundang, yakni antara pesilaq (orang yang mengundang) dengan dipesilaq (orang yang diundang). Tindak tutur menyilaq sepadan dengan ilokusi direktif. Menurut Searle (dalam Rahardi, 2007: 36) "tindak tutur direktif (directives) adalah bentuk tutur yang dimaksudkan penuturnya untuk membuat pengaruh agar si mitra tutur melakukan tindakan, misalnya memesan (ordering), memerintah (commanding), memohon (requesting), menasehati (advising), dan merekomendasi (recommending)." Fungsi tuturan direktif berorientasi pada penerima pesan. Dalam hal ini, bahasa dapat digunakan untuk memengaruhi orang lain, baik emosi, perasaan, maupun tingkah laku. Sebagai fungsi direktif, bahasa dapat digunakan untuk memberi keterangan, memesan, memerintah, memohon, menasihati, dan merekomendasikan.

Bentuk bahasa yang menggunakan fungsi tuturan direktif, dalam tuturan (1) sebagai berikut:

(1) "Silaq te lalo zikir tipaq balen si Pulan!"

'Mari kita pergi zikir ke rumah si Pulan!'

Fungsi tuturan direktif pada contoh di atas tercermin pada kata kerja yang memiliki makna mengajak atau mengundang (menyilaq). Di dalam sebuah tindak tutur pasti terdapat seorang penutur (pembicara) dan juga lawan tutur (pendengar). Wacana dalam proses menyilaq antara penyilaq (pembicara) dengan orang yang disilaq (pendengar), yakni orang yang diundang dalam berinteraksi untuk menyampaikan pesan (pesilaq-an) yang akan disampaikan tidak lepas dengan penuturan. Sebenarnya, dalam proses menyilaq, tuturan ilokusi direktif tersebut banyak sekali ditemukan. Sebagai data, peneliti meneliti tindak tutur menyilaq pada masyarakat Sasak di Desa Gereneng Kecamatan Sakra Timur.

Tindak tutur menyilaq ini menarik untuk dikaji karena di dalam wacana menyilaq itu sendiri bertautan antara aspek bahasa (tuturan pesilaq-an) dan aspek kontekstual, seperti umur, jabatan, dan status sosial masyarakat yang turut serta dalam menentukan bentuk tuturan. Pertautan ini dapat memunculkan berbagai variasi tuturan dalam wacana menyilaq itu sendiri. Selain itu, perilaku hidup masyarakat Sasak di pedesaan yang masih begitu memperhatikan faktor jarak sosial (keluarga, kerabat, teman, sahabat, rekanan, kolega, dll.) akan sangat menentukan pula ragam tindak tutur dan strategi yang digunakan oleh penutur 
dan mitra tutur dalam suatu wacana menyilaq. Adapun hal yang didiskusikan dalam penelitian ini adalah: (a) bagaimana bentuk tindak tutur menyilaq pada masyarakat Sasak di Desa Gereneng, Kecamatan Sakra Timur?; (b) bagaimana bentuk respons tindak tutur menyilaq pada masyarakat Sasak di Desa Gereneng, Kecamatan Sakra Timur?; (c) bagaimana strategi tindak tutur menyilaq pada masyarakat Sasak di Desa Gereneng, Kecamatan Sakra Timur?; dan (d) bagaimana strategi respons tindak tutur menyilaq pada masyarakat Sasak di Desa Gereneng, Kecamatan Sakra Timur?

\section{METODE PENELITIAN}

Penelitian ini merupakan penelitian deskriptif kualitatif dengan model studi kasus. Sumber data penelitian ini berasar dari informan yang dijaring dengan menggunakan teknik stratified random sampling. Pengumpulan data dilakukan dengan memadukan teknik cakap dan teknik kuesioner berupa teks melengkapi wacana (TMW). Data yang terkumpul kemudian diseleksi dan dianalisis menggunakan metode padan dengan teknik padan ekstralingual sebagai teknik dasarnya untuk menentukan hubungan bahasa dan faktor eksternal yang memengaruhi pemakaian bahasa dalam tindak tutur menyilaq masyarakat Sasak di Desa Gereneng, Kecamatan Sakra Timur. Adapun tahapan dalam analisis data ini adalah (1) tahap reduksi data (data reduction), yaitu kegiatan memilih data yang sesuai dengan objek kajian dalam penelitian; (2) tahap penyajian data (data display), yaitu menyusun informasi atau data secara teratur dan terperinci agar mudah dipahami dan dianalisis; dan (3) tahap penyimpulan (conclusion drawing), yaitu kegiatan menyusun simpulan dari data yang sudah diperoleh.

\section{HASIL DAN PEMABAHASAN}

\section{A. Bentuk Tindak Tutur Menyilaq}

Dari data yang dihimpun, diperoleh gambaran yang beragam mengenai bentuk tuturan yang digunakan oleh penyilaq (orang yang menyilaq) dalam melakukan tuturan menyilaq. Dapat dirumuskan bentuk tindak tutur menyilaq yang dilakukan masyarakat Sasak di Desa Gereng, Kecamatan Sakra Timur, yaitu (a) tuturan menyilaq satu kalimat; (b) tuturan menyilaq dua kalimat; (c) tuturan menyilaq tiga kalimat, dan (d) tuturan menyilaq lebih dari tiga kalimat.

a. Tuturan Menyilaq Satu Kalimat

Tuturan menyilaq pada masyarakat Sasak di Desa Gereneng, Kecamatan Sakra Timur yang berbentuk satu kalimat tampaknya sangat kecil kemungkinannya terjadi. Bahkan, dari data yang diperoleh, hanya didapatkan tiga buah tuturan menyilaq satukalimat. Ciri khas dari tuturan menyilaq satu kalimat adalah tuturan ini langsung menyajikan pesan utama atau inti dari tindakan menyilaq, yaitu ajakan/undangan. Tuturan ini dilakukan seperti pada data (1), (2), dan (3) berikut.

(1) Maaf uninte juluq ne, meton, sengaq melente menyilaq side zikir metang dase pedare papuq nike lemaq malem leq bale.

'Maaf, kawan, saya ingin mengundang Anda untuk hadir zikir 40 hari almarhum kakek kami besok malam di rumah.' 
(2) De dateng doang sikir bareh meton leq bale, ndeh.

'Pokoknya, Anda harus datang tahlilan nanti Saudara.'

(3) Kanak, bereh pade milu rikiran jok bale ah?

'Anak-anak, nanti kalian ikut zikiran ke rumah ya?'

Tuturan seperti data di atas muncul pada tindakan menyilaq dengan mitra tutur yang tergolong usia sebaya atau lebih muda. Ini juga dipengaruhi oleh konteks tuturan yang terjadi secara kebetulan (tak terduga) atau dalam suasana santai seperti tampak pada data (2) dan (3). Mitra tutur yang sebaya atau lebih muda akan mengurangi batas jarak sosial antara para partisipan sehingga tuturan yang muncul bisa dilakukan dengan bahasa yang kasual sehari-hari. Implikasi lain dari mitra tutur yang sebaya adalah lebih longgarnya penyilaq dalam melakukan tindakan menyilaq. Artinya, ia tidak mesti harus mematuhi pakem atau sistematika menyilaq secara menyeluruh. Demikian pula halnya dengan situasi tutur yang bersifat santai akan membuat jarak sosial partisipan menjadi lebih dekat yang berpengaruh pada pemakaian bahasa dan adabmenyilaq yang kaku dan formal.

b. Tuturan Menyilaq Dua Kalimat

Jika mengacu pada Tabel 1, secara kuantitatif, tuturan menyilaq dua kalimat cukup banyak diterapkan oleh masyarakat Desa Gereneng, Kecamatan Sakra Timur, yaitu 58 tuturan. Bentuk-bentuk ini dapat dirinci lagi karena beberapa tuturan memperlihatkan pola yang berbeda dengan tuturan yang lainnya. Tuturan dua kalimatdengan pola paling banyak adalah dalam bentuk salam-pesan. Maksudnya, dalam melaksanakan tindakan menyilaq, pihak penyilaq melakukan tuturan pembuka dengan salam, baru kemudian melanjutkan ke pesan. Tuturan seperti ini tampak pada data (4) dan (5) berikut.

(4) Assalamu'alaikum. Tedateng menyilaq side zikiran bareh malem do'ean wayah saq taek hajinike, silaq.

'Assalamualaikum. Saya datang menyilaq Anda untuk zikiran nanti malam untuk mendoakan orangtua kami yang naik haji.'

(5) Assalamu'alaikum. Silaq Amaq, de dateng bareh malem tipaq gedeng kadus ngendeng doe tolaq balaq.

'Assalamualaikum. Mari, Bapak, Anda datang malam nanti ke rumah kepala dusun untuk melangsungkan doa tolak bala.'

Dari data (4) dan (5) dapat dilihat bahwa salam digunakan untuk mengawali pesan. Tuturan dengan pola memulai dengan salam menjadi penciri masyarakat Sasak, termasuk juga di Desa Gereneng, Kecamatan Sakra Timur. Ketika bertemu dengan teman, salam merupakan hal pertama yang diucapkan. Ini tidak lepas dari kuatnya ajaran agama dijalankan oleh masyarakat. Itu pun terbawa sampai dalam kehidupan sehari-hari, bukan sekadar ketika beribadah atau dalam praktik keagamaan saja. Tidak heran jika hal serupa muncul pula dalam tindak tutur menyilaq di atas.

Pola lain dari bentuk tuturan ini adalah perkenalan-pesan. Ini tampak pada data (6), (7), dan (8).

(6) Salam Amaq Salman, lemaq lat araqn pinaq acare ngurisan nie. Side tepesilaq dating inggas Asar.

'Salam Bapak Salman, lusa beliau mengadakan acara akikah. Anda diharapkan 
untuk hadir ba'da salat Asar.'

(7) Salam Amaq Sar, pengaret sampi, leq bale. Side tepesilaq dateng sikir ngehol pedare Tuan Ibrabim.

'Ada salam Pak Sar, si pengangon sapi di rumah. Anda diharapkan untuk datang zikir haul Haji Ibrahim.'

(8) Niki tiang, Sabri, anakn Gerip eleq Gubuk Lauq. Tiang dateng menyilaq Amaq Rian nyaksian dedaren Guru Manan akad lemaq leq jelo Ahad muri adeqn saq dateng doang basen.

'Ini saya, Sahri, anaknya Gerip dari Gubuk Utara. Saya datang menyilaq Amaq Rian untuk menyaksikan akad nikah anak gadis Guru Manan besok Minggu depan.'

Tuturan (6)-(8) merupakan tuturan dengan menggunakan pola perkenalan-pesan. Meskipun sama-sama menggunakan perkenalan-pesan, tuturan (6) dan (7) hanya memperkenalkan pemilik hajat, sedangkan pada tuturan (8) yang diperkenalkan adalah penyilaq. Perbedaan ini disebabkan oleh faktor jarak sosial. Pada data (6) dan (7), pihak penyilaq berasumsi bahwa dirinya sudah dikenal oleh pihak dipesilaq sehingga ia tidak perlu lagi memperkenalkan diri kepada mitra tuturnya. Sementara pada tuturan (8), penyilaq sadar bahwa dia tidak dikenal oleh mitra tutur, tetapi ia tahu bahwa mitra tutur mengenal latar belakang keluarga pesilaq sehingga ia perlu memperkenalkan dirinya dengan menggunakan hubungan kedekatan dengan orang yang kenal oleh mitra tutur.

Berbeda dengan dua pola sebelumnya, pola ketiga adalah pola pesan-penutup. Pada pola ini, penyilaq langsung menyampaikan pesan utama baru kemudian menutupnya dengan izin pamit. Tuturan seperti ini muncul pada situasi pihak penyilaq berhadapan dengan tetangga. Artinya, mitra tutur adalah orang yang sudah dikenal. Pola ini seperti digambarkan pada data (9).

(9) Salam Kakak leq bale, side tepesilaq ngekahan bijen lemaq inggas asar, nggih. Silaq tiang pamit juluq.

'Salam Kakak saya, Anda diundang pada acara akikah anaknya besok lepas salat Asar. Mari, saya permisi dulu.'

Dari uraian data di atas, tampak bahwa tuturan menyilaq dengan dua kalimat pun hanya berlaku pada mitra tutur yang bukan tokoh. Ini tampaknya dapat dimaklumi karena tuturan menyilaq dengan dua kalimat terkesan dilakukan secara terburu-buru atau sambil lalu. Jika melihat pada partisipan, tuturan ini ditujukan pada partisipan yang sudah dikenal atau yang tidak dikenal, tetapi bukan berasal dari kalangan yang status sosialnya tinggi sehingga tidak mengancam muka mitra tutur.

\section{c. Tuturan Menyilaq Tiga Kalimat}

Tuturan meyilaq tiga kalimat memperlihatkan adanya variasi yang beragam, tidak hanya dari pola tuturan, tetapi juga dari variasi bahasa. Dalam tuturan menyilaq jenis ini, penyilaq kadang kala ditemukan menyisipkan hal-hal yang tidak berkaitan dengan inti/pesan menyilaq, seperti informasi tambahan tentang pemilik hajat, situasi di tempat acara, dan lainlain. Namun, ini justru memberikan warna tersendiri dalam pelaksanaan tuturan menyilaq. Tuturan menyilaq tiga kalimat dapat dilihat dalam data (10) di bawah ini. 
(10) Assalamu'alaikum, Miq. Niki tiang nyampean salam Guru Sahid pesilaq pelungguh nyaksian bijen saq merariq lemaq Ahad. Basen Guru Sahid jaq, teharep gati kerawuhan pelungguh.

'Assalamu'alaikum, Pak. Saya bermaksud menyampaikan salam dari Guru Sahid yang mengharapkan Bapak untuk menjadi saksi pernikahan anak beliau pada hari Minggu besok. Pesan beliau, kedatangan Bapak sangat diharapkan.'

Pada tuturan (10), penyilaq menggunakan ragam bahasa Sasak Alus. Ini disebabkan mitra tutur berlatar belakang bangsawan yang status sosialnya lebih tinggi dibandingkan dengan penyilaq. Tampaknya ini sejalan pula dengan sudut pandang kajian sosiopragmatik tentang jarak sosial. Teori jarak sosial menjelaskan bahwa semakin tinggi status sosial seseorang, semakin jauh jarak sosial antarpartisipan.

Tuturan menyilaq tiga kalimat juga muncul dengan variasi ragam bahasa Sasak Jamak. Ini tampak pada data (11) dan (12) berikut.

(11) Assalamu'alaikum warahmatullahi wabarakatuh.. Ape jaq tegaweq te iAmaq?Ne, tedateng menyilaq side sarakalan bareh malem leq bale, silaq. Kan jaq, wah berangkat Inaq lalo haji.

'Assalamu'alaikum warahmatullahi wabarakatuh. Apa sih yang dikerjakan itu Pak? Ini, saya datang mengundang Anda sarakalan nanti malam di rumah. Kan, ibu (saya) sudah berangkat haji (sehingga butuh didoakan).'

(12) Tenyampean salam juluq ne eleq Amaq Danu basen jaq pesilaq side sikir bareh malem inggas ise. Dendeq sampe ndek dateng, ndeh, sengaq Amaq Danu gati ngepe acare ne. Silaq meno jaq, tepamit juluq jok bale siq lainan.

'Saya menyampaikan salam Bapak Danu untuk mengundang Anda zikir nanti malam ba'da isya. Mohon kiranya Anda untuk tidak berhalangan, sebab Bapak Danu yang punya hajat. Mari kalau begitu, saya pamit mau ke rumah warga yang lain.'

Ada perbedaan mendasar antara tuturan pada data (10) dengan data (11-12). Data 10 menggunakan variasi ragam bahasa Sasak Alus, sedangkan tuturan (11-12) hanya menggunakan tuturan ragam bahasa Sasak Jamak. Artinya, dalam bentuk tuturan tiga kalimat, penyilaq menggunakan ragam bahasa Sasak yang berbeda tergantung konteks tuturan. Selain itu, perbedaan juga terlihat pada strategi tutur yang nanti akan lebih diuraikan secara lebih detail pada subbab 4. Dari sini, dapat ditarik satu pemahaman bahwa semakin panjang tuturan, semakin banyak hal yang diucapkan oleh penyilaq. Bahkan, hal-hal itu tidak ada sama sekali kaitannya dengan maksud kedatangan penyilaq, seperti kalimat kedua data (11), "Ape jaq tegawe tie Amaq?" yang bermaksud menanyakan aktivitas pihak dipesilaq. Namun, ini dapat dimaknai sebagai usaha penyilaq untuk memulai komunikasi dengan mitra tuturnya. Semakin banyak hal/pesan yang disajikan/disampaikan oleh penyilaq kepada pihak dipesilaq mengindikasikan kegigihan penyilaq dalam mendekatkan diri dengan pihak dipesilaq. Ini dilakukan karena penyilaq merasa bahwa dia adalah duta dari pemilik hajat. Sementara dalam tuturan (12) tampak adanya penekanan informasi di pemilik hajat kepada dipesilaq. Ini disebabkan oleh pengetahuan penyilaq bahwa pihak dipesilaq sangat dekat hubungannya dengan pemilik hajat sehingga jika penekanan pesan ditegaskan pada hal informasi tentang pemilik hajat, pihak dipesilaq akan langsung menangkap pesan yang 
disampaikan.

d. Tuturan Menyilaq Lebih dari Tiga Kalimat

Tuturan jenis ini merupakan tuturan yang paling banyak diucapkan oleh penyilaq dibandingkan jenis tuturan yang lain dalam tindak tutur menyilaq yang peneliti temukan. Jika mengacu pada data Tabel 1 terdapat tidak kurang dari 96 tuturan dalam bentuk tuturan menyilaq lebih dari tiga kalimat. Di sini, perlu dijelaskan kembali maksud tuturan menyilaq lebih dari tiga kalimat, yaitu tuturan yang disampaikan dengan menggunakn empat, lima, enam, atau lebih kalimat dalam sekali tindakan menyilaq. Tuturan bentuk ini bisa dilihat pada tuturan (13) dan (14).

\section{B. Bentuk Respons Tindak Tutur Menyilaq}

Hampir sama dengan tuturan menyilaq, respons atas tindak tutur menyilaq juga sangat dipengaruhi oleh berbagai faktor eksternal, seperti mitra tutur, situasi, dan status sosial. Namun, yang paling umum terjadi, respons akan sangat bergantung pada tuturan dari pihak penyilaq. Jika penyilaq menggunakan tuturan ragam bahasa Sasak Alus (seperti ragam kromo dalam bahasa Jawa), ada kemungkinan respons yang diterima juga menggunakan ragam bahasa Sasak Alus. Demikian juga sebaliknya, jika penyilaq menggunakan tuturan ragam bahasa Sasak Jamak (seperti ragam ngoko dalam bahasa Jawa), ada kemungkinan respons yang diterima juga menggunakan ragam bahasa Sasak Jamak. Respons atas tindak tutur menyilaq ini dikelompokkan dalam dua bentuk, yaitu respons menerima dan respons menolaq pesilaqan (undangan).

\section{a. Respons Menerima}

Tuturan yang memperlihatkan respons menerima terjadi dengan tiga variasi, yaitu tuturan satu kalimat, tuturan dua kalimat, dan tuturan lebih dari dua kalimat. Tuturan satu kalimat dapat dilihat pada tuturan (15-17).

(13) Insya Allah tiang dateng bareh.

'Insya Allah, saya datang.'

(14) Ndek semel bae ndeq dateng.

'Malu saya ndak datang (ke acara ini).

(15) Nggih, insya Allah tiang rawuh tipaq gedeng pelungguh.

'Ya, insya Allah saya datang ke rumah Anda.'

Ketiga tuturan ini menggambarkan bentuk respons satu kalimat. Jika dilihat kembali, tampak tuturan tersebut sangat singkat dan hanya berisi informasi kesediaan untuk menghadiri undangan. Meskipun disampaikan secara berbeda-beda, inti dari tuturan (15-17) tetap tidak jauh berbeda, yaitu kesediaan pihak dipesilaq untuk menghadiri undangan pemilik hajat.

Namun, respons menerima tidak selamanya berarti bahwa pihak dipesilaq akan dating ke acara pemilik hajat. Sebab, tindakan menyilaq hanya bagian awal dari rangkaian acara pemilik hajat. Bisa saja nanti pihak dipesilaq tidak hadir meskipun sudah mengatakan kesiapannya. Ini bisa saja disebabkan oleh beberapa faktor, seperti sakit, ada acara lain yang lebih penting, kesibukan di tempat bekerja, atau lupa. Respons penerimaan ini hanya bisa diuji kebenarannya ketika pihak dipesilaq benar-benar hadir di acara pemilik hajat. 


\section{b. Respons Menolak}

Berdasarkan data yang dihimpun, bentuk tuturan respons menolak memiliki ciri utama, yaitu tidak pernah dituturkan dalam betuk satu kalimat. Respons menolak cenderung menggunakan tuturan lebih dari dua kalimat. Ini bisa dilihat pada data (18-19) berikut,

(16) Nggih, tampi asih tiang sampean tipaq Amaq Danu sengaqn saq pesilaq tiang rawuh leq aceren nike. Laguq, tiang ampure beleq-beleq niki sengaq bareh malem jaq tiang sampun bejanji atong mentoaq nike jok dokter. Ndek ape tiang ndeq mele rawuh niki. Sengaq Amaq Danu endah wah maraqsemeton mesaq. Jari, salam ampure tiang be nike tipaq Amaq Danu, nggih. Insya Allah lemaq tiang rawuh jok gedeng Amaq Danu.

'Ya, terima kasih saya kepada Bapak Danu karena sudah diundang di acara tersebut. Namun, saya minta maaf sebesar-besarnya karena nanti malam saya sudah ada janji untuk mengantar mertua saya ke dokter. Bukannya saya tidak ingin datang. Bapak Danu sudah saya anggap saudara sendiri. Jadi, salam maaf saya saja kepada beliau, ya. Insya Allah, besok saya akan ke rumah beliau (sebagai ganti malam ini).'

(17) Lemaq aru? Lamun lemaq aru jaq badeq ndek mauq dateng sengaq araq undangan endah bejulu leq Rumbuk araq sikir. Kan adat jaq saq julu tepejuluq. Laguq, insya Allah bae unin te juluq ne. Lamun ndeq jari jok Rumbuk jaq bale noh tipaq langsung. Girangm saq minaq acare pas ite ndeq mauq no endah kamu ne.

'Besok? Kalau besok mungkin saya tidak bisa hadir karena saya juga mendapat undangan zikir/tahlil ke (Desa) Rumbuk. Ajaran adat juga mengatakan yang dahulu didahulukan. Tapi, insya Allah saja saya katakan dahulu. Kalau besok saya tidak jadi ke Rumbuk, saya pastikan untuk datang ke rumahmu. Kamu juga sering sekali buat acara ketika saya tidak bisa hadir.'

Tuturan pada data (18) merupakan respons atas tindak tutur menyilaq menggunakan ragam bahasa Sasak Alus. Di sini tampak bagaimana pihak dipesilaq berusaha agar ketidakhadirannya bukan dianggap sebagai kesengajaan. Oleh karena itu, digunakan kalimat, "Ndek ape tiang ndeq mele rawuh niki. Sengaq Amaq Danu endah wah maraq semeton mesaq." Kalimat ini bermaksud bahwa pihak dipesilaq sangat ingin sekali hadir, tetapi karena berhalangan (mertua sakit) sehingga tidak bisa hadir. Penguatan pun diberikan dengan mengatakan bahwa pemilik hajat (Bapak Danu) sudah dianggap seperti saudara sendiri. Akan aneh rasanya jika saudara sendiri tidak hadir ketika saudaranya mengadakan kegiatan/acara.

Sementara itu, pada data (19) digunakan tuturan ragam bahasa Sasak Jamak karena penyilaq dianggap masih berusia lebih muda dibandingkan dengan pihak dipesilaq. Namun, yang menarik adalah pemakaian kalimat sangkalan oleh pihak dipesilaq pada tuturan, "Girangm saq minaq acare pas ite ndeq mauq no endah kamu ne." Dalam kalimat ini, pihak dipesilaq mencari pembenaran bahwa pemilik hajat sering kali mengundang di saat pihak dipesilaq tidak bisa hadir. Mungkin saja maksud dipesilaq, kalau bisa, harinya diganti saja agar pihak dipesilaq bisa hadir.

Benang merah dari kedua data di atas adalah dalam menyampaikan penolakan, pihak dipesilaq berusaha agar dirinya tidak sampai dikatakan tidak menghormati 
undangan tersebut. Berbagai argumen pembenaran diberikan tujuannya agar pihak pemilik hajat mau memaklumi ketidakhadiran pihak dipesilaq. Sebab, pihak dipesilaq menyadari benar bahwa menyilaq bukan sekadar undangan biasa. Jika seseorang tidak hadir ketika dipesilaq oleh orang lain, itu seperti tidak menghargai undangan orang lain. Hal inilah yang dikhawatirkan oleh pihak dipesilaq sehingga mengeluarkan berbagai macam argumentasi. Akibatnya, tuturan yang disampaikan pun menjadi lebih panjang.

\section{Strategi Tindak Tutur Menyilaq}

Masyarakat Sasak pada umumnya, termasuk di Desa Gereneng, Kecamatan Sakra Timur, amat jarang menyampaikan informasi secara langsung (to the point) kala berkomunikasi dengan sesamanya. Ini merupakan bagian dari adab dalam berkomunikasi sehingga seringkali informasi/pesan yang seharusnya bisa disampaikan dengan kalimat singkat menjadi panjang dan berputar-putar. Namun, bagi masyarakat (penutur bahasa) Sasak, hal itu menjadi pertanda untuk mengakrabkan diri dan menghormati antarsesama dalam berkomunikasi. Demikian pula yang terjadi pada masyarakat Sasak di Desa Gereneng, Kecamatan Sakra Timur dalam menyilaq. Jika mengacu pada bentuk tuturan menyilaq yang sudah dipaparkan pada subbab 1 sebelumnya dapat diperoleh variasi bentuk tuturan yang di dalamnya memuat strategi tuturan menyilaq yang beragam antara penutur yang satu dengan penutur yang lain. Misalnya, ada tuturan menyilaq yang dimulai dengan salam, tetapi ada pula tuturan yang tidak menyertakan salam pembuka. Semua itu memiliki konsekuensi masing-masing yang akan dibahas secara lebih rinci di subbab ini.

Menyilaq sebagai tradisi dan perilaku sosial tidak hanya berarti mengundang, tetapi wujud eksistensi masyarakat tutur yang ada di sekitar tempat tersebut. Ini mengandung konsekuensi bahwa menyilaq merupakan implikasi dari keinginan pemilik hajat untuk dianggap ada di antara orang sekitarnya. Secara sosial, setiap orang tentunya berharap bahwa setiap kegiatan atau acara yang dilangsungkan secara terbuka dapat dihadiri oleh banyak orang. Setiap orang yang hadir akan memberikan citraan yang berbeda-beda. Misalnya, seseorang yang ketika mengadakan acara perkawinan anaknya, acaranya dihadiri oleh tokohtokoh besar dan banyak anggota masyarakat lainnya. Ini menandakan bahwa orang tersebut memiliki pergaulan yang luas dan amat baik di masyarakat. Tetapi, jika yang hadir hanya sedikit, tentunya orang akan berpikir bahwa orang tersebut tidak pandai bergaul dan eksklusif di kalangan masyarakat.

Inti dari tindak tutur menyilaq adalah agar pihak dipesilaq (orang yang diharapkan kehadirannya oleh pemilik hajat) benar-benar datang ke acara si pemilik hajat. Oleh karena itu, strategi tuturan pihak penyilaq juga akan sangat berpengaruh dalam menentukan dating tidaknya pihak dipesilaq. Masyarakat Desa Gereneng, Kecamatan Sakra Timur menyampaikan tindak tutur menyilaq dengan berbagai bentuk dan cara seperti dibahas dalam subbab 1. Jika dibuatkan secara lengkap, didapatkan rumusan strategi menyilaq pada masyarakat Sasak di Desa Gereneng, Kecamatan Sakra Timur sebagai tertera di bawah ini.

1) Salam Pembuka

Salam pembuka merupakan salam untuk membuka pembicaraan. Salam pembuka yang lazim digunakan masyarakat Sasak di Desa Gereneng adalah assalamu'alaikum atau versi lengkapnya assalamu'alaikum warahmatullahi wabarakatuh. Salam pembuka seperti ini 
menjadi lazim karena rata-rata penduduk Desa Gereneng, Kecamatan Sakra Timur adalah beragama Islam. Dalam ajaran agama Islam, setiap pertemuan dalam bentuk apa pun dianjurkan untuk dimulai dengan mengucap salam. Namun, salam pembuka dalam tindak tutur menyilaq tidak hanya berarti doa, tetapi juga strategi untuk memulai komunikasi dengan pihak dipesilaq.

\section{2) Permohonan Maaf}

Terkadang, dalam tindak tutur menyilaq, penyilaq akan menyampaikan permohonan maaf terlebih dahulu sebelum menyampaikan pesan. Ini terjadi jika pihak dipesilaq ditemukan sedang melakukan aktivitas lain sehingga mesti terhenti sementara oleh kedatangan penyilaq. Kedatangan penyilaq yang tiba-tiba mungkin saja bisa menyita waktu, mendatangkan kejengkelan, atau merusak keasyikan pihak dipesilaq sebelumnya. Oleh karena itu, permohonan maaf perlu disampaikan.

\section{3) Memperkenalkan Diri}

Jika pihak dipesilaq adalah orang yang tidak dikenal, penyilaq mesti memperkenalkan diri terlebih dahulu. Tujuannya, agar pihak dipesilaq memiliki gambaran pengetahuan latar belakang penyilaq. Maksud lain dari memperkenalkan diri adalah agar terjadi hubungan yang baik di antara keduanya sehingga pesan yang disampaikan juga dapat diterima oleh pihak dipesilaq.

4) Memperkenalkan Pemilik Hajat

Dalam pergaulan hidup di masyarakat, seseorang belum tentu dikenal oleh seluruh masyarakat luas. Jika orang seperti ini mengadakan hajatan/kenduri, pastilah akan sulit baginya untuk mengundang semua warga di sela-sela kesibukannya untuk mempersiapkan acaranya pula. Oleh karena itu, penyilaq dibutuhkan untuk membantu pemilik hajat dalam menyampaikan pesan kepada orang lain. Penyilaq yang paham akan kondisi ini akan memilih untuk memperkenalkan pihak pemilik hajat sebelum dia menyampaikan pesannya.

\section{5) Isi/Pesan}

Pesan adalah informasi yang ingin dibagikan oleh penyilaq kepada pihak dipesilaq. Inilah bagian paling penting dalam tindak tutur menyilaq. Yang disampaikan di bagian ini adalah jenis kegiatan dan waktu pelaksanaannya. Meskipun demikian, antara penyilaq yang satu dengan penyilaq yang lain pastinya memiliki cara pendekatan yang berbeda dalam menyampaikan pesan.

6) Harapan

Harapan berisi pesan pemilik hajat yang disampaikan ulang oleh penyilaq sebagai perwakilannya. Harapan merupakan keinginan pemilik hajat agar pihak dipesilaq dapat hadir di acara yang dimaksudkan. Oleh karena itu, dalam menyampaikan tuturan menyilaq, pesilaq biasanya menguatkan tindak tutur menyilaq dengan memberikan harapan. Tujuan utama dari tuturan harapan ini adalah agar pihak dipesilaq merasa diberatkan oleh harapan tersebut sehingga ia memastikan diri untuk hadir dalam acara/kegiatan dimaksud. Selain itu, harapan dapat dijadikan bentuk penghargaan kepada pihak dipesilaq karena mendapatkan pesan khusus dari pihak pemilik hajat.

7) Permohonan Izin Pamit

Jika pesan sudah disampaikan, tugas penyilaq telah berakhir. Pihak dipesilaq sudah 
mendapatkan informasi yang dibutuhkan. Tibalah giliran penyilaq untuk berpamitan pulang atau menuju ke tempat yang lain. Penyilaq akan menyampaikan permohonan izin untuk mengakhiri proses menyilaq dan berpamitan. Tujuan dari permohonan izin ini adalah agar penyilaq tidak ditahan lebih lama lagi di rumah pihak dipesilaq. Tujuan lain adalah penyilaq berharap agar tidak lebih merepotkan pihak dipesilaq karena kedatangannya.

8) Terima Kasih

Ucapan terima kasih disampaikan penyilaq berkaitan dengan sambutan dan keramahan yang diberikan oleh pihak dipesilaq sewaktu menerima pihak penyilaq. Ini juga sebagai bentuk apresiasi dengan mengatasnamakan pihak pemilik hajat kepada pihak dipesilaq.

9) Salam Penutup

Hampir sama dengan salam pembuka, maksud dari salam penutup untuk mengakhiri percakapan. Ketika salam penutup sudah disampaikan, dengan sendirinya tuturan dinyatakan selesai. Semua proses tindak tutur menyilaq sudah dilaksanakan. Penyilaq dapat melakukan aktivitas berikutnya, demikian juga dengan pihak dipesilaq.

Apa yang diuraikan di atas adalah akumulasi strategi yang digunakan oleh penyilaq dalam menyampaikan tindak tutur menyilaq. Namun, tidak semua tuturan menggunakan strategi selengkap ini. Semua itu bergantung juga pada kompetensi penyilaq dan hubungan kedekatan dan status sosial pihak dipesilaq. Oleh karena itu, perlu juga dirumuskan batasan minimal strategi dalam melaksanakan tindak tutur menyilaq oleh masyarakat Sasak di Desa Gereneng, Kecamatan Sakra Timur.

Secara sederhana, tindak tutur menyilaq dapat dilangsungkan dengan mengacu pada strategi berikut: salam pembuka $>$ perkenalan (penyilaq/pemilik hajat) $>$ pesan $>$ salam penutup. Inilah unsur minimal yang harus ada ketika seorang penyilaq melakukan tindak tutur menyilaq yang baik. Boleh saja penutur menggunakan tuturan lebih singkat, seperti data (1), misalnya, tetapi itu akan sangat berisiko untuk mengancam muka pemilik hajat dan pihak dipesilaq. Sebab, semakin singkat tuturan, semakin singkat informasi yang akan diperoleh pihak dipesilaq. Ini akan berakibat pada terjadinya miskomunikasi dalam penyampaian pesan.

\section{Strategi Merespons Tindak Tutur Menyilaq}

Dalam merespons tuturan menyilaq, fokus perhatian pihak dipesilaq berada pada pesan yang disampaikan. Oleh karena itu, dalam merespons pun, pihak dipesilaq akan langsung mengarahkan pembicaraan pada pesan tersebut. Ini karena pihak dipesilaq merupakan orang yang sama sekali tidak memahami informasi yang akan disampaikan. Berbeda dengan penyilaq yang sudah mempersiapkan diri tentang informasi, pihak dipesilaq tidak memiliki gambaran yang pasti tentang hal apa yang akan disampaikan penyilaq. Ketika pesan itu disampaikan, hal itulah yang dipastikan pertama kali. Akibatnya, tidak ada tuturan pembuka sebagai strategi merespons seperti pada tindak tutur menyilaq. Ini bisa dilihat pada tuturan penerimaan dan penolakan pada data (15-19). Semua respons mengarah langsung pada pesan penyilaq. Oleh karena itu, dapat disimpulkan dalam tulisan ini, formula khusus yang dijadikan strategi dalam menyampaikan respons menyilaq belum bisa dideskripsikan. Namun, jika harus membuatkan berdasarkan data yang ada, akan diperoleh 
dua model strategi sesuai dengan jenis respons yang ada, yaitu:

a. Strategi respons menerima

Dalam respons menerima, pihak dipesilaq tidak terlalu bertele-tele dalam menyampaikan tuturan. Yang penting untuk disampaikan adalah memberikan janji kepastian untuk hadir dalam acara. Hanya saja bentuknya yang bermacam-macam sebagaimana dijelaskan dalam subbab 2 di atas.

b. Strategi respons menolak

Dalam respons menolak, pihak dipesilaq menggunakan strategi berbeda, tetapi mirip. Ini bisa diformulasikan seperti berikut.

1) Terima kasih

Berbeda dengan dalam tuturan menyilaq, ucapan terima dalam respons menyilaq berarti kesyukuran dan apresiasi atas kesediaan pemilik hajat untuk mengundang pihak dipesilaq. Ini menandakan bahwa pemilik hajat sangat menghargai keberadaan pihak dipesilaq dan sangat ingin tetap menjalankan silaturahmi dengannya. Ini juga bermakna apresiasi atas kesediaan pemilik hajat untuk merepotkan dirinya membawa utusan dalam diri penyilaq hanya untuk menyampaikan pesan.

2) Permohonan maaf

Permohonan maaf di sini digunakan karena pihak dipesilaq tidak bisa menghadiri undangan yang dimaksud. Pihak dipesilaq mengucapkan maaf karena pemilik hajat sudah mengutus orang agar mengundang dirinya, tetapi karena ia tidak bisa akhirnya utusan ini harus pulang tanpa membawa hasil yang baik. Atas banyaknya kerugian itulah, pihak dipesilaq memohon maaf agar pemilik hajat dan penyilaq tidak tersinggung dan berhenti mengundangnyadi lain kesempatan.

3) Argumentasi

Argumentasi adalah alasan-alasan yang diberikan sebagai dalih/penyangkalan untuk tidak menghadiri undangan. Maksudnya, agar pemilik hajat dan penyilaq dapat memaklumi uzur (keterbatasan) pihak dipesilaq yang juga memiliki urusan atau masalah di hari yang sama dengan hari acara pemilik hajat. Argumentasi ini diucapkan dengan sedemikian rupa dengan maksud pemilik hajat tidak tersinggung dan memaafkan ketidakhadiran pihak dipesilaq.

4) Pesan

Pesan, maksudnya pihak dipesilaq menitipkan pesan kepada pemilik hajat. Pesan di sini bisa berarti doa bagi kelancaran acara, menitip salam kepada pemilik hajat, atau janji khusus kepada pemilik hajat.

\section{SIMPULAN}

Berdasarkan penjelasan dalam pembahasan di atas, dapat disimpulkan beberapa hal sebagai berikut.

1. Dalam tindak tutur menyilaq, terdapat beberapa bentuk tindak tutur yang digunakan oleh masyarakat Sasak di Desa Gereneng, Kecamatan Sakra Timur, yaitu (a) tuturan menyilaq satu kalimat; (b) tuturan menyilaq dua kalimat; (c) tuturan menyilaq tiga kalimat; dan (d) tuturan menyilaq lebih dari tiga kalimat.

2. Dalam merespons tindak tutur menyilaq, masyarakat Sasak di Desa Gereneng, 
Kecamatan Sakra Timur menggunakan dua bentuk respons, yaitu reposns menerima dan respons menolak.

3. Strategi dalam melakukan tindak tutur menyilaq adalah: salam pembuka $>$ memohon maaf $>$ memperkenalkan diri $>$ memperkenalkan pemilik hajat $>$ menyampaikan isi/pesan $>$ harapan $>$ memohon izin pamit $>$ terima kasih $>$ salam penutup.

4. Strategi dalam merespons tindak tutur menyilaq adalah, terdiri dari dua hal: (a) respons menerima, menggunakan tuturan janji kesediaan untuk hadir; dan (b) respons menolak: terima kasih $>$ permohonan maaf $>$ argumentasi $>$ pesan.

\section{DAFTAR PUSTAKA}

Al-Khatib. 2006. "The Pragmatics of Invitation Making and Acceptance in Jordan Society" dalam Journal of Language and Linguistics, Vol. 5, No. 2, Th. 2006, Hal. 272-294.

Austin, J.L. 1962. How to Do Things with Words. Oxford: Oxford University Press.

Abdurrahman. 2006. "Pragmatik; Konsep Dasar Memahami Konteks Tuturan". Journal Ilmu Bahasa dan Sastra. Vol. 1. No. 2: 116-133.

Chaer, Abdul Leonie Agustina. 2004. Sosiolinguistik Perkenalan Awal (Edisi Revisi). Jakarta: Rineka Cipta.

Cutting, Joan. 2008. Pragmatics and Discourse. New York: Routledge.

Mahsun. 2005. Metode Penelitian Bahasa Tahapan Strategi Metode dan Tekniknya. Jakarta: Raja Grafindo Persada.

Margono. 2000. Metodologi Penelitian Pendidikan. Jakarta: Rineka Cipta.

Parera, Jos Daniel. 2004. Teori Semantik. Jakarta: Erlangga.

Prasetyo, Aji. 2010. "Nglulu Dalam Bahasa Jawa". Lingua. Jurnal Bahasa dan Sastra. Volume 6, Nomor 2, Desember 2010.

Prayitno, Harun Joko. 2011. Kesantunan Sosiopragmatik Studi Pemakaian Tindak Direktif di Kalangan Andik SD Berbudaya Jawa. Surakarta: Muhammadiyah University Press.

Rahardi, Kunjana. 2006. Pragmatik: Kesantunan Imperatif Bahasa Imperatif Bahasa Indonesia. Jakarta: Erlangga.

Sudaryanto. 1993. Metode dan Aneka Teknk Analisis Bahasa. Yogyakarta: Duta Wacana University Press.

Sukmadinata, Nana Syaodih. 2011. Metode Penelitian Pendidikan. Bandung: Remaja Rosdakarya Offset.

Syamsuddin, dkk. 2009. Metode Penelitian Pendidikan Bahasa. Bandung: Rosdakarya.

Wijana, I Dewa Putu dan Muhammad Rohmadi. 2009. Analisis Wacana Pragmatik (Kajian Teori dan Analisisnya). Surakarta: Yuma Pustaka.

Wijana, I Dewa Putu. 1996. Dasar-Dasar Pragmatik. Yogyakarta: Andi Offset.

Yusrita, Yanti. 2001. "Tindak Tutur Maaf di dalam Bahasa Indonesia di Kalangan Penutur Minangkabau”. Journal Ilmiah Masyarakat Linguistik Indonesia.No. 1: 93-103. 